\title{
Interwoven Tragedies: Hillsborough, Heysel and denial
}

To lose your son in that way, killed by those people, is beyond sorrow. It is something time cannot cure. It leaves you dead in your heart.

Bruno Guarini, father of one of the 39 Juventus fans killed at Heysel Stadium (Vulliamy 2015).

'Disaster' is the suffix commonly deployed in depictions of the most dreadful chapters in the history of the world's most popular spectator sport: the unextinguished cigarette that caused 56 deaths in a wooden stand in Bradford (1985); the air crashes that foreshortened the lives of players from Torino (1949) and Manchester United (1958); the stadium stampedes and crushes that truncated hundreds of lives from Kathmandu, Buenos Aires and Lima to Moscow, Sheffield and Glasgow. Of these, two stand out as exceptions to the rule of misfortune, incompetence or greed, as something more complex, grievous and culpable than a disaster. Wikipedia may disagree (https://en.wikipedia.org/wiki/Heysel_Stadium_disaster), but 'tragedy' seems far more apposite; a very male tragedy at that. That both involved Liverpool FC - at Brussels' Heysel Stadium on 29 May 1985 and at Sheffield's Hillsborough on 15 April 1989 - is the unhappiest, most divisive, most problematic of coincidences. Yet it would be naïve, at best, to deny any other connection.

Both tragedies, after all, were the product of fear and loathing, loyalty and spite. Unforgivably, in terms of serious debate and recording history faithfully, the truth surrounding the death of 96 spectators at Hillsborough is still being sought in the courts though the key ingredient, contempt for football supporters, cannot be doubted. Not until the clubs were drawn together in the Champions League two decades later did Liverpool - the city, the club and its fans - formally apologise for the deaths at Heysel of 39 spectators, mostly Juventus fans, following a charge by their Merseyside counterparts. A group of 
militant Liverpool supporters marked that 2005 encounter by organising a mosaic across the Kop reading Amicizia (Friendship); the captains, Sami Hyypia and Alessandro del Piero read out the names of the victims, and a delegation from Anfield finally deigned to visit Turin; yet not for a further five years did either club erect a permanent memorial to the dead. 'Incompetence, violence, cover-up, shame and lies' summed up John Foot, author of an acclaimed history of Italian football. 'Many people have an interest in not remembering what happened that night: the players, many fans, the Belgian politicians and police forces' (Sinnott 2012). Jean-Philippe Leclaire, who was editor-in-chief of L'Equipe when he wrote Le Heysel: Une tragédie européene, contends that Juventus have been as keen to forget Heysel as the club they beat that night (Vulliamy 2015).

'The Italians themselves would view the disaster with amazing objectivity and comprehension,' attested Brian Glanville, who covered this endlessly troubling era for the alleged people's opiate from both sides of the continental fence, for the Sunday Times and Corriere dello Sport. 'There, blame was chiefly reserved for the shockingly inept Belgian authorities...for the pitiful police' (Glanville 1991, 159). A dilapidated ground, a collapsed wall and inadequate policing all assuredly played their part, but as the more cynical Juventus fans have observed, this 'amazing objectivity and comprehension' can be explained by the fact that that was the night the club won Europe's premier club trophy for the first time: nothing can be allowed to sully that precious memory. For many years, the club website ignored the grisly context.

Fourteen Liverpool supporters were imprisoned for involuntary manslaughter along with the police captain in charge of security; Albert Roosens, secretary-general of the Belgian Football Union was given a six-month suspended sentence for 'regrettable negligence', as were two senior police officers whose conduct was described by the judge as 'extraordinary'. 
Yet what happened at Heysel is now regularly referred to as 'The Tragedy That Dare Not Speak Its Name'.

Terry Wilson, who served nine months of a five-year jail sentence, became a schoolteacher and born-again Christian; less admirably, he claimed in a BBC documentary that his only crime was to help his fellow supporters (Heysel 1985: Requiem for a Cup Final 2005). In a letter to the Liverpool Echo, another of the accused was quicker to express contrition, albeit anonymously:

I snapped and lost my head. I ran towards the Italian who had pulled a knife in front of me and started fighting with him. I started hitting him... I started hitting any Italian who was anywhere near. It suddenly dawned on me what I was doing. I ran to the top of the terrace at the back of the ground and stopped. I couldn't believe what I had done. One minute I was acting like a yob, the next I was crying. My life as decent person is over. I couldn't believe what I had done. One moment I was acting like a yob, the next I started to cry...God, forgive us. (The Anfield Wrap 2015a)

To suggest that the fatal charge by those wearing red scarves in any way begat the unconscionable behaviour of the police at Hillsborough is to wade into toxic waters. Revealing, though, are the adrenaline-fired thoughts of a young officer elicited by Hunter Davies in The Glory Game, a diary of Tottenham Hotspur's 1971-72 season and a milestone in football reportage. Davies, a Spurs supporter, had boarded the 12.40pm 'hooligan' special ferrying his fellow fans from Euston to Coventry. From his seat he saw gangs, powered by alcohol, fight with each other. At Coventry station the police were waiting; everyone was searched. Davies fell into conversation with a new recruit who had joined the local Task Force only the previous week. Was he frightened? 
'I'm scared stiff. I stand at the back surrounded by them and I think if one pulls a knife, I've had it.' He knew that only one or two might have a knife. Most of the lads were probably OK. But all the same, he couldn't understand why any of them came. They couldn't possibly enjoy the match. I said it was the crowd excitement. I'd already felt it when they were stampeding off the train. In the middle of all the noise and shouting, you really did feel you'd taken over the city. I said they were all in rotten jobs, from rotten homes, all the usual things. There was no other excitement or meaning in their lives. 'I suppose I can understand that. I'm in the police for the excitement. I'm longing for that call in the middle of the night and we'll have to go belting down the street. I suppose I'm lucky. My excitement's legal. Theirs isn't.' (Davies 1973, 106-7)

Nor would it be politic to point out that the fences that contributed so heavily to the deaths at Hillsborough would not have been there but for the pitch invasions beloved by fans of a certain disposition. To shrink from expressing such views, however, would be to shy away from the unappetising aspects of the ties that bind.

$* * * * * * * * * * * * * *$

At the heart of the story lies Liverpool itself, a city that won international sympathy in the wake of Hillsborough - all the more so as truth drowned lies - yet still managed to arouse venomous prejudices. 'There are soapy politicians to make a pet of Liverpool, and Liverpool is always standing by to make a pet of itself,' wrote Edward Pearce in The Times after seeing the floral tributes at Anfield. "Why us? Why are we treated like animals?" To which the plain answer is that a good and sufficient minority of you behave like animals' (Pearce 1989). The most notorious broadside came from The Spectator's Simon Heffer: 'They see themselves whenever possible as victims, and resent their victim status; yet at the same time they wallow in it.' This broadside had been approved by Boris Johnson, the magazine's editor 
and future mayor of London, who was immediately dispatched to the city by the Conservative leader, Michael Howard, to apologise. Even Alan Bennett, one of the most respected English playwrights of the past half-century, admitted to mixed if not jaundiced emotions as he watched the survivors being reunited with their families at Lime Street Station: 'I find myself thinking it would be Liverpool, that sentimental, self-dramatising place' (Bennett 1994).

I didn't know Liverpool well enough to feel remotely so equivocal. As befits a child of the 1960s still in thrall to The Beatles, I retain an extremely soft spot for the city and its inhabitants. Summer pilgrimages to The Cavern, Strawberry Field and Penny Lane with my children have served as regular reminders of the creativity, iconoclasm and daring behind that world-changing Mersey beat. Never mind Salzburg, Vienna, New York or Chicago: has any city ever been so elevated to wider consciousness by music? Not that the cultural attractions stop there. Along with Manchester's Mike Leigh, Alan Bleasdale is my favourite British dramatist. Never, moreover, have I seen football played so sublimely, for such a sustained period, as when Kenny Dalglish and John Barnes were in artistic harness at Anfield in the 1980s. I hope, therefore, that what follows is seen less as condemnation than a statement of deep regret.

\section{The road to self-destruction}

Jean Baudrillard saw Heysel as a turning-point. 'Heysel changed everything about the culture of English football, much of it ultimately for the better. Its antithesis was probably Italia 90 when, in a fog of spliffed-out bliss and to the soundtrack of New Order, English football began its long renaissance. Since then we've moved on to the age of the "post-fan", the age of consumers rather than supporters. The truth is that the collapsed wall at Heysel was a deadly metaphor for the gathering destructive forces that brought English football culture to 
its knees. Most significantly, Heysel marked the culmination of a long trajectory of violence and neglect in England's football culture, which, despite the success of its clubs in Europe, was heading inexorably for self-destruction. Looking back, it is a miracle that anyone has made it out of the wreckage' (Quoted in Hussey 2005).

Baudrillard struck a chord with Richard Giulianotti. 'For Baudrillard (1993, 79, quoted in Giulianotti 2012), hooligans are "no different from terrorists", because they "carry participation to its tragic limit, while at the same time daring the State to respond with violence, to liquidate them". In the UK context, such violence was also a kind of fatalistic response to the Thatcher government's highly provocative, draconian "state terrorism" against "unemployed hooligans", striking miners and other citizens. The “calculated bloody-mindedness" of Thatcher's social policies drove these marginalised groups into suicidal actions, such as publicly discredited strikes or violence inside stadiums. For the fans at Heysel, "it is as though she [Thatcher] turns them into commandos herself, then sends them abroad; she condemns them, of course, but their brutality remains the very same brutality that she demonstrates in the exercise of her power"' (Baudrillard, 1993, 78). None of this, though, should blind us to the root of what happened at Heysel. That it is so often glossed over or diminished can be attributed, primarily if not exclusively, to Hillsborough: with sensitivities heightened by the findings of the inquiry, references to the culpability of Liverpool fans, and hence to the tragedy itself, are deemed distasteful. A sociologist colleague recently told me, somewhat sheepishly, that it would be 'career suicide' for him to reassess Heysel, to reopen this Pandora's Box. To cite but one instance of distortion, the estimable David Goldblatt (2014) ascribed the Heysel tragedy to 'a stadium crush': the same words so often used as a shorthand explanation for the tragedy at Hillsborough. Some argue that there is no need to rake over such deeply unpleasant and 
distressing ground when the causes of those 39 deaths are so widely known; others counter that the denial that appears to afflict so many makes doing so imperative.

\section{Chronicle of death foretold}

To the journalists who saw it coming, what happened at Heysel was unremittingly sad vindication for the media's relentless focus on hooliganism. To Glanville, while the horrendous events can be blamed on numerous factors, none 'exonerates the Liverpool fans':

As Mrs Thatcher would remark a couple of days after the horrors, it was an appalling thing that one set of supporters could not stand beside another without being attacked (Glanville 1991, 157).

John Williams, who has probably spent more time analysing 'the English disease' than anyone, remains sceptical about official accounts of what happened at Heysel ('the nadir') because, he has claimed, it was so uncharacteristic of Liverpool followers. As one himself, this generosity is understandable. 'There were often fights at matches, but in general Liverpool fans were not really interested in violence, although they could look after themselves. The idea of being a "scally" was to be above the kind of pointless destruction which neanderthals like Leeds or Chelsea or England fans went in for. That is why Liverpool fans were never organised into firms; there were just small bunches of mates who stood together at the match or in the pub. It was okay to steal - as long as what you stole was designer stuff from Europe or wherever. It was just funny stuff, larking about' (Hussey 2005). 
That well-travelled photo of a dart protruding from the eye of young Manchester United fan at Anfield in the late 1970s points to something darker. Glanville, for one, regarded a sizeable segment of Liverpool fans as rather more objectionable than mere 'scallys':

As a club, Liverpool, alas, were not remotely matched by their notorious supporters. Among these there was beyond doubt a core of decent, largely middle-aged, peaceful, pleasant fans, who would share the mature, sensible attitudes of the club itself. There were also, as fans from other clubs all over the country knew all too well, thousands of brutalised, violent toughs, whose excesses had been known for many years (Glanville 1991, 157).

When 'the detested' Manchester United went to Anfield shortly before Heysel, recollected Glanville, 'the city had seemed awash with hatred'.

Coaches and trains of United's supporters were stoned. Mechanics would run out of garages to scream abuse at the coaches as they went by. When United, just a few weeks later, came once more to Merseyside to play Liverpool, this time in the FA Cup semi-final at Goodison Park, Liverpool's supporters were firing flares into the Manchester fans' sections. Quite where Liverpool's following had gained its spurious reputation for good conduct with a blinkered press was obscure. But then, journalists see little or nothing from the Press Box, nothing of what goes on, often sinister and violent, in the surrounding streets and alleys, at railway stations. Unless they are privy to good, first-hand information, journalists accept the public, distorted image; in this case, a misleadingly benign one. Nor would it be enough to say that violence among Liverpool fans could be explained by unemployment, the crumbling and deliquescence of a doomed city. The behaviour of Everton's fans, in Rotterdam for the Cup Winners' Cup Final two weeks before, had been exemplary (Glanville 1991, 157). 
Tony Evans recounted his experiences following Liverpool's European campaigns with bittersweet verve and soul in Far Foreign Land (2006). A spectator at Heysel, and later football editor and columnist at The Times, he is still tormented by nightmares - and unhesitant in citing the genesis of the tragedy: 'At the European Cup final against Roma a year earlier, the Italian fans had stabbed many of us in the backside' (Interview with author 2015). This was confirmed by David Pye, a mature student at the University of Brighton who was in attendance at Heysel and Hillsborough. His memories of that match in Rome, played at the ground Roma share with Lazio, the Stadio Olimpico, remain chilling:

A week spent sightseeing in Rome proved to be idyllically hospitable, and event-free, as the majority of Italians encountered professed to being Lazio fans - Roma's sworn enemy. Hence free food in restaurants and an astonishing number of 'Forza Liverpool' cries echoing out of every shop. Curiosity demanded that I uncovered the reality that, in fact, the bulk of Roma's support came from poor and disadvantaged 'housing projects' way beyond the ancient walls and ramparts. These largely unemployed, disaffected, right-wing youths apparently had little business in Rome itself and rarely travelled into the prefecture of the tourist spots, unless it was to 'pickpocket, bag-snatch on their Vespas, or to shoplift in the main department stores', to quote a Roman bank official I spoke to at the time.

So it was with some trepidation that we, as true Liverpool fans, approached the largely rebuilt Olimpico Stadium on that glorious and balmy evening. The police presence was massive, heavily armed, and with ferocious German shepherd attack dogs that seemed to curl their lip and growl as we 'foreigners' walked by. You sensed immediately they were expecting trouble, but seemed as fearful of their notorious home ground 'Tifosi' compatriots as they were of us, and whatever reputation we had gained. Commonsense dictated that a group of us had already booked into the youth hostel that was part of the Olympic Stadium 
park, meaning we could pass under the radar of Roma fans patrolling the railway, bus and Metro stations.

As we approached the ground Liverpool fans were heavily searched, with any conceivable weapon confiscated - though significantly not ejected from the ground - which suggested there was a knife culture and that confiscation of fans' weapons was an accepted part of the game in Italy at the time. Again, this did not bode well.

We could clearly see hordes of Roma fans pouring into other sections of the ground unchecked and unmolested. It was impossible to overstate the importance of this game to Italians - in their capital, with its history and traditions, in their most revered stadium, with a team of chequered history desperate to rekindle their own glory days, playing on their own ground. How could they lose? They dare not lose. (Interview with author 2015)

That they did, believes Pye, led directly to the ensuing barbarism.

The Liverpool fans appeared to be set up by the police and Carabinieri in the immediate aftermath, being prevented from leaving the stadium until, it appeared, the Tifosi were ready for them. By now armed with baseball bats, clubs, chair legs, pool cues, chains and knives, a pitched battle ensued in the narrow streets of the ancient capital. Many English supporters and innocent tourists alike were trapped, beaten, brutalised and stabbed, for the most part in the buttocks - the ultimate slight, a trademark of Mussolini's Fascist vigilante mobs and Mafiosi enforcers. (Interview with author 2015)

$* * * * * * * * * * * *$

The day before the $30^{\text {th }}$ anniversary of the Heysel tragedy, Andy Heaton, author of The Anfield Wrap blog, ran an extract from Heysel: A European Tragedy - an unpublished book completed in 1989 by Sir Harry Livermore, a former Lord Mayor of Liverpool whose law 
firm Silverman Livermore represented 16 of the accused in the Heysel trial. 'Il Messagero claimed to have evidence of a premeditated campaign to "hunt down the English", and added: "The gravest aspect is that the English did nothing to provoke the violence." Milan's Corriere della Serra claimed these Roman louts "did not demonstrate calm and self-control which are typical British characteristics". Italy's main sporting daily added [that] it turned into "a night of vile blind violence that disappointment cannot justify" (The Anfield Wrap 2015).

Come the following May, vengeance was in the air. 'I wouldn't say it was about revenge,' quibbles Evans, 'but the mood when we went to Brussels was "That's not going to happen to us again"” (Interview with author 2015).

\section{'The Heysel Card'}

Patrick Barclay is a widely respected Hungarian-Scot whose award-winning reporting has enlightened readers of, among others, The Guardian, Independent, Sunday Telegraph and The Times for nearly half a century. While working for the last in 2012, he received a tweet from one 'CharlieChucksBalls': 'Do you get any lower than taking Murdoch's cash?' Instructed to engage with his readers in the now-customary fashion, Barclay returned the volley with interest: 'See your point. But yes, you can. For example, you can be in a crowd that crushes 39 people to death.' In one of the more temperate retorts, Andy Heaton accused Barclay of 'playing the Heysel card' (2012) and responding 'in a manner normally exhibited by those he has no doubt pontificated over as scum who blight the game'. Barclay's claim that his retort was fair comment was derided as 'ridiculous'; the notion 'that every Liverpool fan should feel responsible for Heysel was Basil Fawlty-esque in its crassness'.

Three years later, Barclay reflected ruefully on the unholy trinity - Heysel, Hillsborough and hooliganism - and the perils of social media: 
I was wrong to have sent that tweet. A spot of alcohol didn't help. Almost as soon as sent it I took it down, but later that night I restored it. I suspect it betrayed my anger at the way Heysel has been subject to such denial by Liverpool fans. It really is the tragedy that dares not speak its name.

I wasn't at Heysel but I remember Barry Davies' brilliant BBC commentary where he expressed the shame he felt at the crowd trouble - 'Who are these British people who come here and cause problems?' When hooliganism was at its destructive height, I favoured the club membership scheme advocated by Thatcher. And I did see 'soft' hooliganism at Hillsborough. People were drinking and chanting abuse - and what about the surging that exacerbated the crush of bodies? Had Kelvin MacKenzie composed a headline reading 'Here's a tiny bit of the truth' he wouldn't have been wrong.

If it hadn't have been for the hooligans there wouldn't have been any fencing, and if there hadn't been any fencing nobody would have died. When people did clamber over, the police sent them back again. Their job, as they saw it, was to keep fans off the pitch. I'll never forget the FA Cup final between Liverpool and Everton not long after Hillsborough, when the police were stretched across the Wembley pitch for that very reason. I couldn't believe it. (Interview with author 2015)

\section{An inconvenient truth}

Leading the Heysel investigation was Bill Sergeant, Detective Chief Inspector of the Mersey Police and a Liverpool supporter:

We made 27 arrests on suspicion of manslaughter - the only extraditable offence applicable - of which 60 per cent were from Liverpool and the remainder from places that ranged from Aberdeen to Ipswich. Some already had convictions for football-related violence...My 
investigations never indicated any evidence of extreme right-wing instigation or coordination of events that night. The then Liverpool chairman, John Smith, had been quoted suggesting this. I interviewed him and he claimed he had been misquoted (Jackson 2005).

Otello Lorentini lost his son that night. Come the $20^{\text {th }}$ anniversary, he was the president of the Association of Families of Heysel Victims:

I was relaxing, reading a newspaper, when I saw a single English hooligan. He jumped over a small fence and came charging towards us. Then, many more followed. They had lumps of terrace concrete, Coke bottles, beer bottles, rocks and even knives. Everyone panicked. There were seven or eight policemen standing on the pitch side of the fencing. We pleaded with them to call for reinforcements. But none came.

I thought we would die. Everyone moved away from the charging Liverpool fans and, in the crush, the wall collapsed. This was actually lucky because otherwise thousands may have been killed. I can still see the face of one hooligan who was about to strike me with an iron rod. I was fortunate, though, because he began hitting someone else. (Jackson 2005)

In Fever Pitch (1992), the book that did so much to return a measure of dignity to football fandom in England, Nick Hornby confessed to guilt by association:

I think this is why I felt quite so ashamed by the events of that night. I knew that Arsenal fans might have done the same, and that if Arsenal had been playing in the Heysel that night then I would certainly have been there - not fighting, or running at people, but very much a part of the community that spawned this sort of behaviour... The kids' stuff that proved murderous in Brussels belonged firmly and clearly on a continuum of apparently harmless but obviously threatening acts - violent chants, wanker signs, the whole, petty hard-act works - in which a very large minority of fans had been indulging for nearly 20 years. In short Heysel was an 
organic part of a culture that many of us, myself included, had contributed towards. (Hornby 1991)

Liverpool's best-known supporter, the DJ John Peel, and his partner, Sheila Ravenscroft, were, she recalled, 'positioned directly opposite where the fans had massed...[it] was one of the most terrifying and disturbing experiences either of us ever had...there was an almighty roar as the wall collapsed...John grabbed my arm and steered me out of the stadium, warning me to hide my Liverpool scarf as we hurried away' (Peel and Ravenscroft 2005). Never again would Peel return to the Anfield stands. Only after declining an invitation to Hillsborough four years later did he make an 'utterly spontaneous' pilgrimage to the ground that had brought him so many happy afternoons and evenings: 'John was surprised to find in himself the apparently mediaeval instinct that had drawn him to Liverpool' (Ibid).

In a searching investigation for Observer Sport Monthly marking the $20^{\text {th }}$ anniversary of Heysel, Andrew Hussey found it telling that neither of Liverpool's best-known playwrights, Bleasdale nor Willy Russell, had yet turned his creative attention to this minefield. That said, as the journalist and Liverpool supporter Brian Reade saw it, in saying he would never return to Anfield, Bleasdale had made his 'inner turmoil' public:

Because if this was what football had been reduced to, then what was the point? How could you look your children in the eye and tell them this was a sport worthy of investing a lifetime's belief and passion when it had sunk to such depths? (Reade 2009)

\section{Thirty years on}

On 29 May 2015, representatives of the Hillsborough bereaved joined members of Liverpool's 1985 European Cup final squad for a private memorial service at Anfield. The previous night, Juventus had held a commemorative mass at the church of the Grande Madre 
di Dio in Turin. 'For too many years, these 39 victims have been subject to scorn with the sole aim of attacking the black-and-white colours,' read the club's announcement, castigating the way Juventus have been taunted by rival clubs and their followers. Yet censorship persisted. Domenico Laudadio, creator of an online memorial, had also written a theatrical monologue about Heysel; so heavily did Juventus dilute it, the project was cancelled. 'They don't want to speak about Heysel and responsibility,' said Francesco Caremani, a friend of the Lorentini family and author of Heysel: The Truth, the only account approved by the Association for the Families of Heysel Victims, 'because I think it is a club with an image, a brand, with relationships with Uefa, with Liverpool, with Belgium' (Hart 2015).

Given the near-daily revelations of the ongoing Hillsborough inquiry, how would the English media respond to the $30^{\text {th }}$ anniversary of Heysel? Asked at the start of 2015 whether he would commemorate it, Tim Nicholls, sports editor of the London Evening Standard, insisted that editorial merits would be the lone consideration. His predecessor Neil Robinson, who also saw service as sports editor at the Independent titles until late 2014, ducked the bouncer with a gleam in his eye: 'Thirty years isn't that big an anniversary, is it?' (Interview with author 2014). More seriously, he described it as 'a serious and complex dilemma', compounded by an age of internet trolls, (anti)social media and instant global damnation - 'and especially for The Sun'. Despite strenuous and repeated efforts by management, sales of the market-leading tabloid in Liverpool had never recovered since the night, three days after Hillsborough, when editor Kelvin MacKenzie decided to bill as 'The Truth' the lies propagated by the South Yorkshire police.

At the time, Nicholls was too young to have seen the horror unfold at Heysel; Robinson, now in his fifties, was not. Alex Butler, the long-serving Sunday Times sports editor, is of a similar vintage, hence his decision to publish Tony Evans's mea culpa on the $20^{\text {th }}$ anniversary, to which we will return. 'Journalistically, I think age matters,' believes Raymond Boyle, 
Professor of Communications at the University of Glasgow. 'If you didn't see what went on back then, if you didn't live through it, you're less susceptible to the imposed narratives' (Interview with author 2015).

In the event, coverage of the $30^{\text {th }}$ anniversary was widespread, primarily through an Italian lens. Nicholls went with the flow, not least because Juventus were due to play in the Champions League final a few days later. In the Daily Mail, Andrea Lorentini vented his fury at the way events had been re-framed for more comfortable public consumption. 'In one part they read us they had Michel Platini scoring the decisive penalty and cry. It's false. That is completely false. He celebrated like a normal game. You only have to watch the video' (Lawton 2015). Caremani, too, found it exceedingly difficult to forgive this perceived callousness, though some Juventus players have claimed that they were ordered to celebrate victory with their supporters. 'They knew about the deaths, they knew everything. There are no excuses or sociological theories to explain [their] behaviour' (Smith 2015).

While The Times - possibly out of respect for the sports desk's Liverpudlian constituents did not commemorate the anniversary, the Telegraph, Guardian and Independent did. 'I saw a lot of bad drunkenness,' remembered Paul Fry. 'There was a jeweller whose shop windows had been stoved in by fans running wild. There was glass all over the cobbles of La GrandPlace. It was absolutely disgraceful. As the match approached, the mood had changed' (Brown 2015). The violence, he insisted, 'was all one way, from Liverpool to Juventus. There was nothing coming back.'

I was right at the back of that pen, and bits of rock were breaking off because the fans were just kicking the terraces apart. The first time I understood that something awful was unfolding was when somebody got some railings and carted a body off, covered in a big flag. Then an arm fell out from underneath. 
'The swell of vitriol towards the English for their part in this, the hideous upshot of years of hooliganism across Europe, stirred an acute discomfiture among many of the players and onlookers who survived,' wrote Oliver Brown in the Telegraph, who interviewed Fry as well as Mark Lawrenson, a member of the Liverpool team that night. 'I had a Belgian girlfriend at the time,' said Fry, 'but I felt I couldn't go and see her afterwards, because I was so embarrassed to be English.' For Lawrenson, too, the first instinct was to hide. 'As players, for whatever reason, we all felt guilty. At the airport the next day, we got spat upon. Even the bus that took us there was surrounded by very irate Juventus fans. We all just wanted to get out of the country.' The 'rush to forget was as instantaneous as it was unseemly', argued Brown. 'Within a few days of getting back,' recollected Lawrenson, 'I went to a service at the Catholic Cathedral in Liverpool - and [Heysel] didn’t get a mention' (Brown 2015).

Predictions that The Sun would overlook the anniversary - and thus curry favour with their estimated 12,000 Liverpudlian readers - were quashed in a double-page spread written by Steven Howard, the paper's long-serving chief sportswriter. Perhaps understandably, he felt compelled to point out that he had interviewed two Liverpool players that week, captain Phil Neal and Ian Rush, whose column he ghosted: 'I only say all this to show that many years ago this newspaper had as good a relationship with Liverpool as any' (Howard 2015). He was not reticient, however, in painting the scene as he saw it:

As the press bus drew into the stadium, it passed a group of Liverpool supporters stripped to the waist in the warm sunshine. One or two were swigging from a whisky bottle...Italian families comforting some of the 600 injured greeted us with shouts of 'English murderers' and police had to intervene to prevent them from extracting revenge...After a few hours' sleep, I walked to the Grand Place, Brussels' main square, where I discovered three brothers from Liverpool surrounded by a group of Belgians screaming 'Assassins'. One restaurant manager shouted: 'Why are you still here? Haven't you pigs done enough?' Turning to me, 
he said: 'Last night they broke my windows, urinated in my restaurant and terrified my customers. Many didn't even go to the game - just stood there drinking and throwing glasses.' The brothers, like other Liverpool fans, blamed the police. (Howard 2015)

\section{Towards acceptance}

That the match proceeded under such dire circumstances now seems criminal, yet what lingers even longer is the disconnection between Heysel and Hillsborough. These tragedies are still treated by many as distinct entities yet were part of the same byzantine problem. 'Liverpool's uncertain position on Heysel was made doubly vexed by Hillsborough,' surmised Brown. 'Emotionally, the outrage that the club attracted in 1985 and the agonies that it experienced in 1989 might be fiendishly difficult to reconcile, but there are historical connections. As Foot puts it: “A Belgian government fell over Heysel. It was a huge political scandal. It was also a major turning point for British football. Put Heysel and Hillsborough together, and consider the ban, and this was the moment that football changed"' (Brown 2015).

Howard quoted From Where I Was Standing, a book written by Chris Rowland, a Liverpool fan, in the immediate aftermath of Heysel, 'purely as a form of catharsis' (Rowland 2009). Extracts were due to be published in the Liverpool Echo in late 1989, but the timing could not have been worse: the manuscript was delivered on 15 April, the day of the Hillsborough tragedy. Serialisation was out of the question. One reflection in particular resonates: the manslaughterers of Heysel 'besmirched their own club's proud name and brought shame, disrepute and universal vilification to each one of us that we have still not shaken off' (Rowland 2009, quoted in Howard).

Still, it was hard not to sense that enduring denial in the Liverpool Echo. Prominent, as ever, were the views of Peter Hooton, who as a member of the Liverpool 28 Improvements 
Committee in Cantril Farm had invited 18 Juventus fans to visit Liverpool in August 1985, a venture funded by the John Moores Foundation and supported by Liverpool City Council.

There was no attempt at saying sorry because we didn't feel any guilt. That might look bad in black and white, but we'd been having a laugh with Juventus fans all through the day of the match. Organising the visit was a way of saying ordinary people can get on. We didn't want to brush what had happened under the carpet and wanted to show the Italians they could come to our city and be welcomed. (Shennan 2015)

Such sentiments reaffirm the view that acceptance remains distant. Acceptance that the main culprits were not the stadium authorities, Uefa, the Brussels police, cheap beer, the allegedly sensationalist media nor even the plight of the working-classes in Thatcher's Britain, but a group of men who felt entitled to brutally impose their masculinity on another group of men at a football match. And hence acceptance that one reason the police acted so unconscionably in Sheffield four springs later stemmed from that 'disrepute and universal vilification'.

On the $20^{\text {th }}$ anniversary of the Heysel tragedy, Tony Evans had had the courage to compose that aforementioned mea culpa for the Sunday Times, recalling his own willing, beer-charged role:

A large proportion of Liverpool fans seemed to have lost control. We met a group of mates who had come by coach. A fellow passenger we all knew had leapt off as soon as they arrived and attacked two people, one an Italian, with an iron bar...The disaster has a long causal chain - stabbings and beatings in Rome, hair-trigger tempers, aggression on both sides, excessive drinking, poor policing and a stadium ripe for disaster. Remove any one link and the game may have passed off peacefully. But it didn't. So, Evertonians sing, with pathetic self-pity, 'Thirty-nine Italians can't be wrong.' Well they weren't. We were. I was. 
When we met, one word sprang again and again from Evans's lips: 'denial'. This, to him, is the main barrier to closure. Post-Hillsborough, however understandably, far too many people have been blinded by it, and not exclusively Liverpool followers. 'I wasn't so bad,' claimed Evans.

I was just a prick. But I did play a very, very small role in something that ended up with people dead. For a lot of people, it seems to me, there wasn't even any empathy until after 1989. Now there's a new generation who think Heysel was nothing to do with us. It was. At least some of us. (thisisanfield.com, 2008)

\section{What if?}

Not one of the 14 Liverpool fans found guilty of playing a part in the fatalities at Heysel served more than 18 months in jail. It is hard not to wonder whether stiffer penalties would have made a difference. Not so much in preventing the Hillsborough deaths as in forestalling the recent revival in football-related hooliganism among English grandfathers, by no means all of them working-class by origin.

It was recently enlightening, therefore, to oversee an investigation by one of my undergraduate students focusing on the growing belief that the 2016 European Championships could be blighted by violent hooliganism, as confirmed to him by a highranking police source. Fears that an apparent admiration for his subjects would obscure the student's perception of the wider context proved unfounded. Interviews with convicted hooligans recalled the laddish boastfulness so beloved by those working in that grotesquely popular genre known as 'hoolie lit', but he had read widely, assembled a diverse range of views - including those of an eminent psychologist - and, over the course of a year-long investigation, found his outlook changing: 
I've always been interested in hooliganism from watching documentaries, movies and YouTube clips and I almost admired and revered them. I saw them as modern-day Robin Hoods or Braveheart figures standing up to the authority. Meeting the actual men behind the films and at the forefront of the documentaries and YouTube clips was actually disappointing. They were just juvenile-minded and couldn't really hold a conversation unless they were talking about fighting. (Email to author 2015)

Perhaps the most sobering and lasting lesson of Heysel and Hillsborough is that, three decades on, it can be said of neither that they broke football's links with the ugly face of masculinity. The extensive loss of life did not even seem to have a short-term impact on crowd misbehaviour. Despite a 42 per cent drop in arrests at Football League grounds 'and a comparable drop in evictions in the season after Heysel', note Williams et al, 'in 1986-87 both sets of figures were on the rise again...by 33 per cent and 48 per cent'. Total arrests rose again in 1987-88 (from 5,502 to 6,147) and again in 1988-89 (to 6,185). Even in the season after Hillsborough, they barely dipped to 5,945 (Sir Norman Chester Centre 2001). By then, furthermore, much of the violence had relocated to side streets, pubs and clubs. The Taylor Report and its recommendation of all-seater stadiums rang the curtain down on an era only the more mindless aggressors remember fondly. That some of us recoil whenever the clamour for 'safe standing' gathers momentum underlines the depth of the scars.

According to Caremani, the deaths in Sheffield could never have occurred had the lessons of 1985 been heeded as they should:

From 1985 to 1989, the English were only angry about being banned from Europe. Heysel and Hillsborough had three important similarities: the disorganisation of the authorities, the behaviour of the police, and the fact that innocent people died. If the English had understood 
Heysel, Hillsborough today would only be the name of a stadium, not of a disaster (Brown 2015).

This prompts one final, counter-factual thought: what if the Hillsborough tragedy had occurred in 1985 ? It is almost impossible to imagine that the truth would not have been suppressed as it was. But had English clubs not been banned from European competition, could the spite that fuelled the Heysel tragedy - however justified - have produced a similar outcome, whether in Brussels or somewhere else? To doubt it is to underestimate the violent undercurrent that, in 1980s Britain, made football the love that dare not speak its name.

\section{REFERENCES}

J. Baudrillard (1993), The Transparency of Evil, London: Verso, quoted in Giulianotti

A. Bennett (1994), Writing Home, London: Faber \& Faber, p. 289

O. Brown, 'Heysel disaster of 1985 is football's forgotten tragedy and Liverpool and Juventus fans' minimal reaction prompts hurt', Daily Telegraph, 28 May, http://www.telegraph.co.uk/sport/football/teams/liverpool/11635476/Heysel-disaster-of1985-is-footballs-forgotten-tragedy-and-Liverpool-and-Juventus-minimal-reaction-prolongshurt.html

H. Davies (1973), The Glory Game, London: Sphere (pbk)

T. Evans (2005), Sunday Times, quoted in 'Our Day of Shame', LFCHistory.net, http://www.lfchistory.net/Articles/Article/3228

R. Giulianotti (2012) 'Sport mega-events and “terrorism”: A critical analysis', International Review for the Sociology of Sport, 47:3, 307-323

B. Glanville (1991), Champions of Europe: The history, romance and intrigue of the European Cup, London: Guinness Publishing

D. Goldblatt (2014), 'How the England football team came to embody Englishness', The Guardian, 23 October, http://www.theguardian.com/news/2014/oct/23/-sp-how-englandfootball-team-came-embody-englishness

S. Hart (2015), 'Heysel disaster 30th anniversary: Italian journalist remembers a tragedy that was "hidden" for so long', The Independent, 28 May,

http://www.independent.co.uk/sport/football/news-and-comment/heysel-disaster-30thanniversary-an-italian-journalist-remembers-a-tragedy-that-was-hidden-for-so-long$\underline{10283163 . h t m l}$ 
A. Heaton (2012), 'Heysel: A Line Crossed', Theanfieldwrap.com, 8 February, http://www.theanfieldwrap.com/2012/02/heysel-a-line-crossed/

A.Heaton (2015a), 'Heysel 30 Years: 'Oh God, what have we done', 28 May, http://www.theanfieldwrap.com/2015/05/heysel-30-years-oh-god-what-have-we-done/

N. Hornby, Fever Pitch (1998), Riverhead Books (pbk), p. 156

S. Howard (2015), 'Some had taken ten minutes to die. I went to a hospital where I saw grown men sat sobbing', The Sun, 29 May, pp. 62-63

A. Hussey (2005), 'How Heysel's lost lives saved a sport', Observer Sport Monthly, 3 April, http://www.theguardian.com/football/2005/apr/03/newsstory.sport14

J. Jackson (2005), 'The witnesses', Observer Sports Monthly, 3 April, http://www.theguardian.com/football/2005/apr/03/newsstory.sport

M. Lawton, '30 years on from the Heysel Stadium tragedy', Daily Mail, 29 May, http://www.dailymail.co.uk/sport/football/article-3102282/30-years-Heysel-Stadium-tragedySportsmail-visits-family-Italy-life-torn-apart-night-European-Cup-final-JuventusLiverpool.html

E. Pearce (1989), The Times, 16 October

J. Peel and S. Ravenscroft (2005), Margrave of the Marshes, Bantam Press, pp.332-3

B. Reade (2009), 44 Years With The Same Bird: A Liverpudlian Love Affair, London: Pan, p. 145

C. Rowland (2009), From Where I Was Standing: A Liverpool Supporter's View of the Heysel Stadium Tragedy, GPRF Publishing (pbk), Foreword

P. Shennan, 'Heysel 30 years on - Peter Hooton: "If we had any idea people had died, we would have walked out", Liverpool Echo, 23 May,

http://www.liverpoolecho.co.uk/news/heysel-30-years---peter-9254188

J. Sinnott (2012), 'The horror of Heysel: Football's forgotten tragedy?', CNN.com, 31 October, http://edition.cnn.com/2012/10/31/sport/football/football-heysel-hillsboroughjuventus-liverpool/

Sir Norman Chester Centre for Football Research (2001), Fact Sheet 1 - Football and Football Hooliganism, p. 3, http://www.furd.org/resources/fs1.pdf

R. Smith (2015), 'Beacon of Heysel casts a shadow', The Times, 4 June, p. 64

thisianfield.com (2008), http://www.thisisanfield.com/2008/06/kopblog-meets-tony-evans/

E. Vulliamy (2015), 'Juventus hope cup success will honour memory of "forgotten" Heysel victims', The Observer, 10 May, p. 25

J. Williams, E. Dunning, P. Murphy (1984), Hooligans Abroad: The Behaviour and Control of English Fans in Continental Europe, Oxford: Routledge

\section{Documentaries}


Heysel 1985: Requiem for a Cup Final (2005), BBC2, first broadcast 17 April, https://www.youtube.com/watch?v=3ix7TkB9gok

\section{Interviews}

Patrick Barclay: Victoria Station, 23 January 2015

Raymond Boyle: Phone interview, 3 February 2015

Kieran Curtin: Email interview, 29 May 2015

Tony Evans: Pimlico, 12 January 2015

David Pye: Eastbourne, 26 May 2015

Neil Robinson: Kensington, 12 December 2014 